\title{
Harvesting impacts on commonly used medicinal tree species (Catha edulis and Rapanea melanophloeos) under different land management regimes in the Mpumalanga Lowveld, South Africa
}

\section{J. ВоTHA, E.T.F. WITKOWSKI and C.M. SHACKLETON}

Botha, J., E.T.F. Witkowski and C.M. Shackleton. 2004. Harvesting impacts on commonly used medicinal tree species (Catha edulis and Rapanea melanophloeos) under different land management regimes in the Mpumalanga Lowveld, South Africa. Koedoe 47(2): 1-18. Pretoria. ISSN 0075-6458.

Harvesting of products from plants in the wild is widespread throughout southern Africa. Particularly important products are plant parts used in traditional medicine. However, the impacts of harvesting practices are rarely quantified, with as yet insufficient generic rules across species and life forms. This limits the predictive ability to monitor and manage the affected populations. This paper examines the harvesting impact on two popular woody medicinal species used throughout sub-Saharan Africa, namely Catha edulis (Vahl) Forssk. ex Endl. (bushman's tea) and Rapanea melanophloeos (L.) Mez. (Cape beech).

In both species, basal diameters, heights, and the number of size classes in the harvested populations were lower than in unharvested. Densities of harvested populations were higher in both species, including densities of young plants, but the frequency of individuals in larger size classes was lower. The populations of both species being harvested for medicinal products appeared to be withstanding the current levels of harvesting, but the population structure of $C$. edulis populations being harvested for poles on the roadside and near human settlements had been substantially altered. Despite the resilience of the two species to harvesting for medicinal products, loss of habitat or changes in land use pose a threat to a number of the assessed populations.

Key words: density, disturbance, dominance, harvesting, impact, medicinal plants, size class.

J. Botha and E.T.F. Witkowski, Restoration and Conservation Biology Research Group, School of Animal, Plant and Environmental Sciences, University of the Witwatersrand, P.O. Wits, 2050 Republic of South Africa; C.M. Shackleton, Department of Environmental Science, Rhodes University, Grahamstown, 6140 Republic of South Africa (c.shackleton@ru.ac.za).

\section{Introduction}

Disturbance factors frequently have greater effects in determining plant community structure, composition and functioning than do the primary abiotic variables (Grime 1979). The effects of any single disturbance or stress are multidimensional, being influenced by its nature, intensity, timing, duration, frequency and interaction with other disturbance factors, as well as the characteristics of the community or species being disturbed. Consequently, they are frequently difficult to predict. Yet, in the face of accel- erating land transformation (Lambin et al. 2001) there is an increasing need to be able to predict the effects and outcomes of particular disturbance regimens on species, populations and communities, at a range of spatial scales, before potentially irreversible losses occur.

In southern Africa, past and present research efforts into the effects of disturbance have focussed on changes in species composition at a community level, essentially within a preservationist paradigm. Yet changes in community and population structure often occur before major shifts in species composi- 
tion, or species loss (Harper 1977; Shackleton 1993), and are a useful indicator of management and disturbance impact. Changes in size class profile of key species, or communities, may alert managers to situations of declining recruitment (Walker et al. 1986; Shackleton et al. 1994; Wiegand et al. 2000; Wilson \& Witkowski 2003) and hence can be regarded as a useful threshold of concern.

A widespread disturbance to plant populations in southern Africa, and elsewhere, is the harvesting of plants from the wild (Hoffman 1997; Dzerefos \& Witkowski 2001). This can be for daily subsistence needs of rural communities, such as fuelwood or wild fruits, but increasingly it is being driven by the need of poor rural households to generate cash incomes (Mander 1998; Braedt \& Standa-Gunda 2000; Shackleton \& Shackleton 2000). Much commercialisation happens at a local level, but equally significant is the supply of plant parts and products to external markets, such as to tourists, regional urban centres, and even export markets.

The intensity of harvesting of specific plant species is influenced by resource abundance, accessibility and market demand. It often decreases with increasing distance from human settlements, transport routes and decreased accessibility of harvesting sites (Konstant et al. 1995; Cawe \& Ntloko 1997; Luoga et al. 2002). The techniques used by commercial harvesters, or those not resident in the area, often tend to cause higher damage to target species than local resource users (Cunningham 1992; Botha 1998; Luoga et al. 2000), although impact tends to be lower where land and/or resource tenure is strong (Crook \& Clapp 1998).

Household and commercial demand for traditional medicines based on wild plants is a particularly large harvesting sector in South Africa (Mander 1998; Williams et al. 2000; Botha et al. 2004a, 2004b). This parallels the growth of the trade throughout the rest of the continent with the expansion of urban populations (Marshall 1998). It is estimated that almost $70 \%$ of South Africa's 40 million consumers make use of traditional medicine to some degree and approximately 30000 households derive income from trading in such plants within KwaZulu-Natal Province alone (Mander 1998).

Catha edulis (Vahl) Forssk. ex Endl. (Bushman's tea) (Celastraceae) and Rapanea melanophloeos (L.) Mez. (Cape beech) (Myrsinaceae) are two popular woody medicinal species used throughout sub-Saharan Africa. In Afro-Arabian cultures, the leaves of the former are traditionally chewed to relieve fatigue and induce euphoria, but production and marketing are now generally prohibited due to side effects (Van Wyk et al. 1997). Roots and bark are traded in medicinal plant markets in Mpumalanga Province of South Africa (Botha et al. 2001), while bark and leaves have been recorded in the urban markets of Gauteng Province (Williams et al. 2001). Bark and roots of $R$. melanophloeos are utilised medicinally, but only the bark has been recorded in markets in Mpumalanga (Botha et al. 2001), Limpopo Province (Mander 1997), KwaZuluNatal (Cunningham 1992) and Gauteng (Williams et al. 2000). Although ranked only $65^{\text {th }}$ out of 120 species in a trade study in Limpopo (Mander 1997), R. melanophloeos was one of ten species most commonly nominated as 'popular' in Gauteng markets (Williams et al. 2000). Perceptions of demand in markets in the Lowveld of Mpumalanga (the low lying plains to the east of the Drakensberg escarpment) were divided; $50 \%$ of the respondents believed that this species was in high demand, while $50 \%$ said that there was little demand for it (Botha 2001). However, traditional healers listed $R$. melanophloeos as one of their most frequently used plants. In addition to their medicinal value, the wood of $C$. edulis is used for building, as wood pulp and to make furniture, and carvings, while that of $R$. melanophloeos is utilised for building materials and woodwork.

Although both species occur in many regions of southern Africa, both have restricted distributions in Mpumalanga, with habitats often under pressure through changing land use. Nevertheless, vendors in the Lowveld 


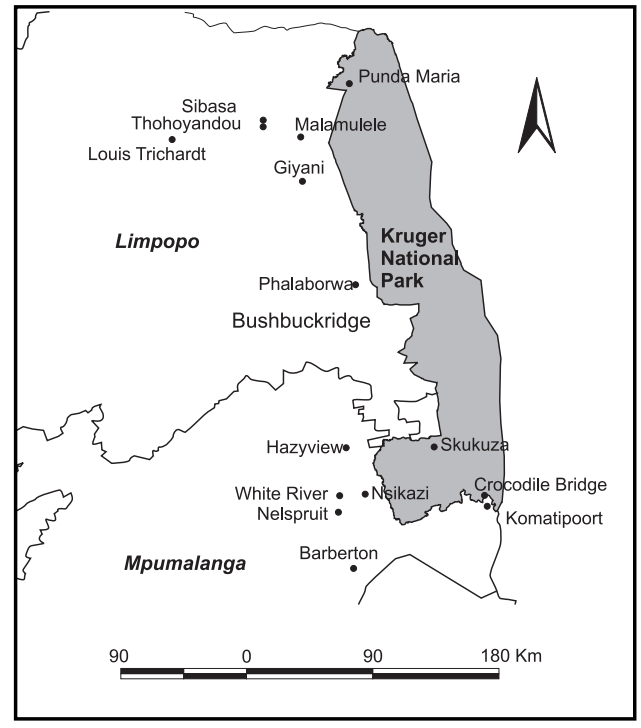

Fig. 1. The localities of the assessed Catha edulis and Rapanea melanophloeos populations.

reported that both species are readily available (Botha et al. 2001). Catha edulis is classed on the Red Data list as vulnerable in the neighbouring province of KwaZuluNatal (Hilton-Taylor 1996). Thus, because of the perceived continuing high demand, but decline in a neighbouring province, local conservationists deemed it important to obtain greater knowledge of the population status of the species in the Mpumalanga Lowveld as part of a broader regional study on the medicinal plant trade (Botha 2001), and to set the basis for prediction of harvesting impacts. Plant demographic surveys are a cost effective means of assessing the impact of harvesting on plant populations, while simultaneously providing baseline data to enable the development of management strategies and for future monitoring (Witkowski et al. 1994).

Within this context, this paper reports on patterns of harvesting of $C$. edulis and $R$. melanophloeos populations under different land management regimes in Mpumalanga, South Africa, as a case example facing conservation and management of popular medi- cinal species elsewhere in Africa and the developing world.

\section{Study area}

Populations of both species were identified on the basis of local knowledge and accessibility in the Lowveld region of Mpumalanga, centred near the towns of Hazyview and Barberton, approximately $100 \mathrm{~km}$ apart (Fig. 1). Rainfall in this region occurs mainly in the hot summer months (October to May). Mean annual rainfall in the two areas is between 900 and $1200 \mathrm{~mm}$ (Institute for Soil, Climate and Water 2000, pers. comm.). The mean maximum temperature in the warmest month (January) is over $25^{\circ} \mathrm{C}$ and the minimum is $18.5^{\circ} \mathrm{C}$ at Hazyview and $15.9^{\circ} \mathrm{C}$ at Barberton. In winter, mean maximum and minimum temperatures are approximately 3-4 degrees lower. Frost is rare. The natural vegetation of the Lowveld is savanna, being dense under high rainfall sites and less so in more arid sites. Being high rainfall sites, both Barberton and Hazyview fall in the Sour Lowveld Bushveld vegetation type (Low \& Rebelo 1986) dominated by, amongst others, Combretum species, Terminalia sericea, Acacia species, Pterocarpus angolensis and Parinari curatellifolia. The shrub layer is characterised by taxa such as Dichrostachys cinerea, Antidesma venosum, Pavetta species and Maytenus species.

\section{Methods}

\section{Field sampling}

For C. edulis, eight populations were sampled; five that were subject to different intensities of harvesting and three unharvested populations. One harvested population occurred on communal land, one at the side of a public road and three on land under commercial forest plantations, of increasing distance away from human settlements. Of the three unharvested populations, one was on a private farm in a fragment of natural vegetation surrounded by farm- 
land (banana and mango plantations), and two were in a provincial protected area (Songimvelo Game Reserve). One of these was growing within and alongside a perennial streambed subject to occasional flooding. The other occurred on a drainage line, and experienced infrequent fires.

Five populations of $R$. melanophloeos were sampled; three harvested and two unharvested. Of the three harvested sites, two were on commercial forestry plantation land, and one on communal land. The forestry sites were burnt biennially. Both the unharvested populations were on forestry land, one near Hazyview and the other near Barberton.

Total counts of a population were carried out in a particular stand or plot, depending on the size of the population; nine plots or populations for $C$. edulis and seven for $R$. melanophloeos. Plot sizes varied according to the distribution of the target species, but were usually $20 \times 40 \mathrm{~m}$, or $20 \times 30 \mathrm{~m}$. As heights may be modified through natural or anthropogenic disturbance, both heights and basal diameters were measured, the latter at $30 \mathrm{~cm}$ above the ground as some individuals branched below breast height. Each stem of multi-stemmed trees was measured and its vigour assessed. Desiccated or rotting stems, with no shoots or other signs of life, were classified as dead. Stressed stems were those showing signs of disease, for example, rotting or desiccated branches, but part of the plant was still living or it was coppicing. External damage to the stem was assessed on a scale adapted from Cunningham (1992), where $0=$ no damage; $1=\leq 10 \%$ of the bark below $2 \mathrm{~m}$ was damaged; $2=11-25 \%$ of the bark below $2 \mathrm{~m}$ was damaged; $3=26-50 \%$ of the bark below $2 \mathrm{~m}$ was damaged; $4=51-75 \%$ of the bark below $2 \mathrm{~m}$ was damaged; $5=$ the stem was ringbarked; $6=$ $76-100 \%$ of the bark below $2 \mathrm{~m}$ was damaged and $7=$ the stem was chopped. The cause of damage was also noted. The number of coppice shoots was recorded as a measure of coppicing vigour.

At some sites, the roots of $C$. edulis had also been harvested. To assess the percentage survival of plants that had been harvested for root material, the extent of root damage was assessed according to the proportion of disturbed surface area radiating out from the base of the stem (Botha 2001): $0=$ no harvesting; $1=<10 \%$; $2=11-25 \%$; $3=26-50 \% ; 4=51-$ $75 \% ; 5=>76 \%$.

\section{Data and statistical analysis}

The equivalent basal diameter was calculated for multi-stemmed individuals. Size classes were grouped into basal diameters of $5 \mathrm{~cm}$ increments, apart from size classes $1(0-1 \mathrm{~cm})$ and $2(2-5 \mathrm{~cm})$. Size class 1 included seedlings, coppices and stems from the previous season that had died back during the non-growing season (Shackleton et al. 1994) and were termed 'young plants'. Size class distributions of harvested and unharvested populations were compared by means of Kolmogorov-Smirnov Goodness of Fit tests. The percentages of trees of harvestable size were calculated according to the size classes of populations that were currently being harvested. Chi squared $\left(\chi^{2}\right)$ analyses were performed to compare the proportions of trees of harvestable sizes in harvested and unharvested populations, as well as the proportions of individuals that had survived after harvesting. Smaller size classes were pooled to ensure a minimum frequency of five in each class. Basal diameter and height variations between harvested and unharvested populations were compared using non-parametric statistics (Kruskal Wallis and Mann Whitney $U$ tests).

Quotients between the numbers of trees in successive size classes were calculated to assess the stability of populations (Meyer 1952). Fluctuating quotients indicate an unstable population, while the quotient between the numbers of trees in successive diameter classes approaches a constant value in a stable population. Stability may also be assessed through Simpson's index of dominance (C) and the permutation index $(\mathrm{P})$. The former describes the probability that any two trees drawn at random from the same community are of the same species or, in this case, from the same size class (Pielou 1977, Wiegand et al. 2000) (equation 1). The evenness of occupation of size classes is measured, ignoring the order in which size classes are arranged (Wiegand et al. 2000). Values above 0.1 reveal that the size frequency is steeper than would be expected from an exponentially declining population (i.e. the size classes are arranged in descending order), while values below 0.1 show that the size classes are more evenly distributed.

$$
\mathrm{C}=1 / \mathrm{N}(\mathrm{N}-1) \sum_{i=1}^{\mathrm{k}} \mathrm{N}_{i}\left(\mathrm{~N}_{i}-1\right)
$$

where $\mathrm{N}$ is the total number of trees and $\mathrm{N}_{i}$ the number of trees in class $i$, and $\mathrm{k}$ is the number of size classes.

The permutation index assesses the deviation of a population from a monotonic decline, which would be expected in an "ideal" population. It is the sum of the absolute distances between the expected and real location (rank) of all size classes, and ignores the relative frequency of different size classes (equation 2) (Wiegand et al. 2000). The permutation index is 
higher in a discontinuous size class distribution than in a continuous, monotonically declining population.

$$
\mathrm{P}=\sum_{i=1}^{\mathrm{k}}\left|\mathrm{J}_{i}-i\right| ; \quad \mathrm{J}_{i}=1,2, \ldots \ldots . ., \mathrm{k}
$$

where $J_{i}$ is the rank of size class $i$ ( $i=1$ for the smallest trees), with the highest rank $\left(J_{i}=1\right)$ given to the most frequent size class.

\section{Results}

\section{Population size and density}

The densities of harvested $C$. edulis populations were significantly higher than those of the unharvested sites. The former ranged from 767 to 9800 trees/ha (3047 \pm 1706 trees/ha), while the unharvested varied from 20 to 85 trees/ha (52 \pm 19 trees/ha) (Table 1$)$. There was no significant difference between the population sizes of harvested and unharvested populations (393 \pm 175 and $313 \pm 131$ trees, respectively).

The density of harvested $R$. melanophloeos populations ranged from 789-8200 trees/ha while the unharvested populations ranged from 750-1013 trees/ha, but they were not significantly different (3864 \pm 1464 \& $882 \pm 132$ trees/ha, respectively). Similarly, population sizes of harvested $R$. melano- phloeos were higher than unharvested (1056 $\pm 973 \& 136 \pm 16$, respectively), but this was not significant (Table 1).

The densities of young plants in harvested C. edulis populations were significantly higher than in unharvested populations $(2192 \pm 1516 \& 149 \pm 126$ trees/ha, respectively). There was a highly significant difference in the relative proportion of plants occurring in size class $0-1 \mathrm{~cm}$ in the harvested populations compared with the unharvested populations (71\% and $7 \%$, respectively) (Fig. 2a). The frequencies of $C$. edulis in the larger size classes was low in the harvested populations. Size class 6-10 $\mathrm{cm}$ comprised only $8 \%$ of the population, and size class $11-15 \mathrm{~cm} 4 \%$, compared with $21 \%$ and $12 \%$, respectively, for the unharvested populations. The densities of $R$. melanophloeos individuals in size class 1 on harvested sites (range 367 to 6700 trees/ha) tended to be higher than those on unharvested (range 60 to 910 trees/ha) but this was not significant $(2783 \pm 1249$ and $485 \pm 425$ trees/ha, respectively).

\section{Size class distribution}

The size class distribution (basal diameters) of harvested $C$. edulis populations was significantly different from unharvested ones $\left(\mathrm{D}_{1507,127}=0.64 ; p<0.005\right)$. The basal diameters of harvested populations were signifi-

Table 1

Population parameters (Mean $\pm S E$ ) of harvested and unharvested Catha edulis and Rapanea melanophloeos populations (Range is provided in brackets below the mean)

\begin{tabular}{|c|c|c|c|c|c|c|c|c|}
\hline Species & $\begin{array}{l}\text { Site } \\
\text { treatment }\end{array}$ & $\begin{array}{c}\text { Estimated } \\
\text { population } \\
\text { size (no.) }\end{array}$ & $\begin{array}{l}\text { Population } \\
\text { density } \\
\text { (trees/ha) }\end{array}$ & $\begin{array}{c}\text { Young plant } \\
\text { density } \\
\text { (no./ha) }\end{array}$ & $\begin{array}{l}\text { Basal } \\
\text { diameter } \\
(\mathrm{cm})\end{array}$ & $\begin{array}{l}\text { Height } \\
\text { (m) }\end{array}$ & $\begin{array}{l}\text { Simpson's } \\
\text { Dominance } \\
\text { index (C) }\end{array}$ & $\begin{array}{l}\text { Permutation } \\
\text { index (P) }\end{array}$ \\
\hline \multirow[t]{3}{*}{ Catha edulis } & Harvested & $\begin{array}{c}393 \pm 175 \\
(96-1000)\end{array}$ & $\begin{array}{l}3047 \pm 1706 \\
(767-9800)\end{array}$ & $\begin{array}{c}2192 \pm 1516 \\
(75-8188)\end{array}$ & $\begin{array}{c}2.6 \pm 0.1 \\
(0.1-31.8)\end{array}$ & $\begin{array}{c}1.6 \pm 0.1 \\
(0.1-18.0)\end{array}$ & 0.71 & 4 \\
\hline & Unharvested & $\begin{array}{l}313 \pm 131 \\
(60-500)\end{array}$ & $\begin{array}{c}52 \pm 19 \\
(20-85)\end{array}$ & $\begin{array}{l}149 \pm 126 \\
(20-402)\end{array}$ & $\begin{array}{c}8.3 \pm 0.7 \\
(0.1-29.9)\end{array}$ & $\begin{array}{c}2.0 \pm 0.1 \\
(0.2-9.0)\end{array}$ & 0.32 & 2 \\
\hline & $p$ values & $p>0.05$ & $p<0.05$ & $p<0.05$ & $p<0.01$ & $p<0.01$ & & \\
\hline \multirow[t]{3}{*}{$\begin{array}{l}\text { Rapanea } \\
\text { melanophloeos }\end{array}$} & Harvested & $1056 \pm 973$ & $\begin{array}{c}3864 \pm 1464 \\
(789-8200)\end{array}$ & $\begin{array}{c}2783 \pm 1249 \\
(367-6700)\end{array}$ & $\begin{array}{c}3.1 \pm 0.2 \\
(0.1-27.1)\end{array}$ & $\begin{array}{c}1.1 \pm 0.0 \\
(0.5-7.0)\end{array}$ & 0.67 & 2 \\
\hline & Unharvested & $136 \pm 16$ & $\begin{array}{c}882 \pm 132 \\
(750-1013)\end{array}$ & $\begin{array}{l}485 \pm 425 \\
(60-910)\end{array}$ & $\begin{array}{c}9.4 \pm 0.7 \\
(0.1-34.1)\end{array}$ & $\begin{array}{l}2.2 \pm 0.2 \\
(0.1-12)\end{array}$ & 0.28 & 6 \\
\hline & $p$ values & $p>0.05$ & $p>0.05$ & $p>0.05$ & $p<0.01$ & $p<0.01$ & & \\
\hline
\end{tabular}


(a)
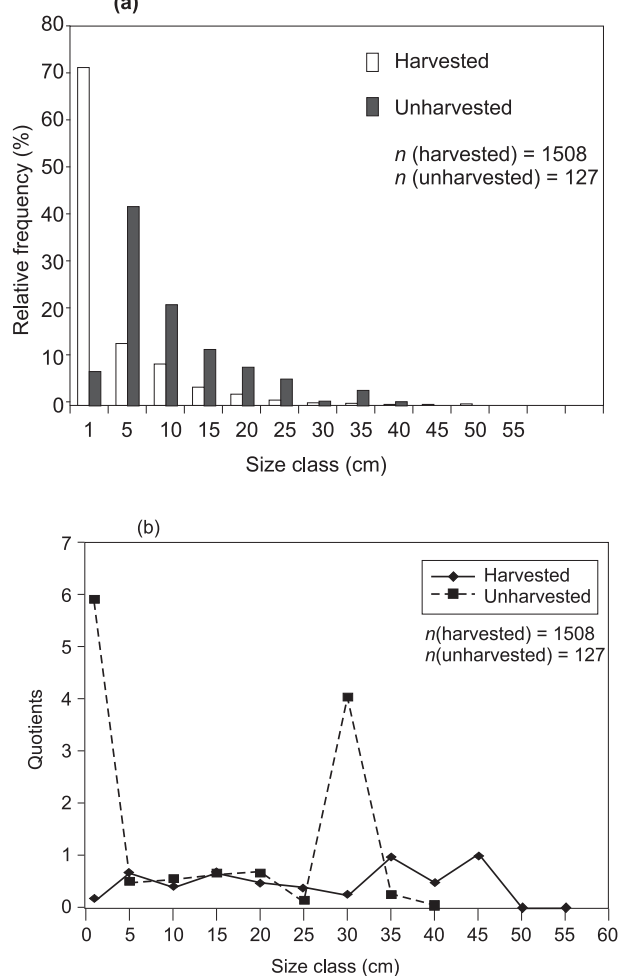

Fig. 2. Population structure of harvested and unharvested Catha edulis populations (a) relative frequencies and (b) quotients between numbers of trees in successive size classes.

cantly lower than those of unharvested populations (2.6 $\pm 0.1 \& 8.3 \pm 0.7 \mathrm{~cm}$, respectively) (Table 1; Fig. 2a). Although Fig. 2a shows higher basal diameters for the harvested populations, this is due to larger individuals growing on one site, namely, the forestry population near Barberton. Higher means are due to relatively higher frequencies of larger individuals in a population. Similarly, the heights of harvested populations were significantly lower than those of the unharvested (1.6 $\pm 0.1 \mathrm{~m} \& 2.0 \pm 0.1 \mathrm{~m}$, respectively), although the maximum height for harvested populations was higher than that in the unharvested (Table 1). Individuals were absent from size classes on the roadside $C$. edulis population near Hazyview, and only the first four size classes $(0-15 \mathrm{~cm})$ on the
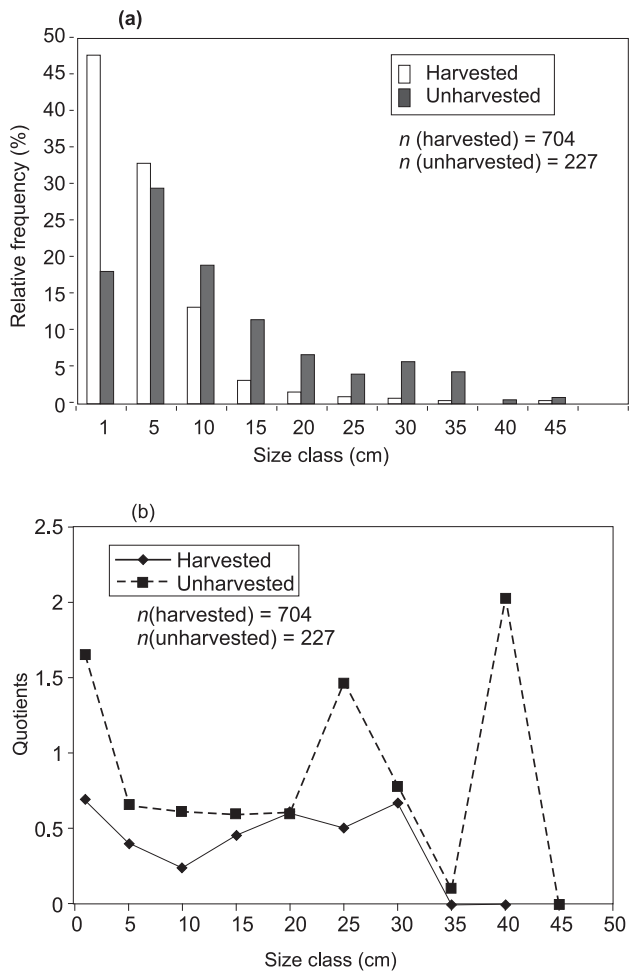

Fig. 3. Population structure of harvested and unharvested Rapanea melanophloeos populations (a) relative frequencies and (b) quotients between numbers of trees in successive size classes.

communal site had individuals (Figs. 4d \& $4 \mathrm{e})$. There were no size classes with frequencies of zero in the harvested forestry populations near Barberton (Figs. 4a-c).

There was a significant difference between the size class distributions (basal diameters) of harvested and unharvested $R$. melanophloeos populations $\quad\left(\mathrm{D}_{704,227}=0.35 ; \quad p<0.005\right)$. Mean basal diameters of harvested $R$. melanophloeos were significantly lower than plants in the unharvested populations (3.1 \pm $0.2 \& 9.4 \pm 0.7 \mathrm{~cm}$, respectively) (Table 1 ; Fig. 3). Similarly, plant height in the harvested populations was significantly lower than in the unharvested $(1.1 \pm 0.0 \mathrm{~m}$ and $2.2 \pm$ $0.2 \mathrm{~m}$, respectively). 

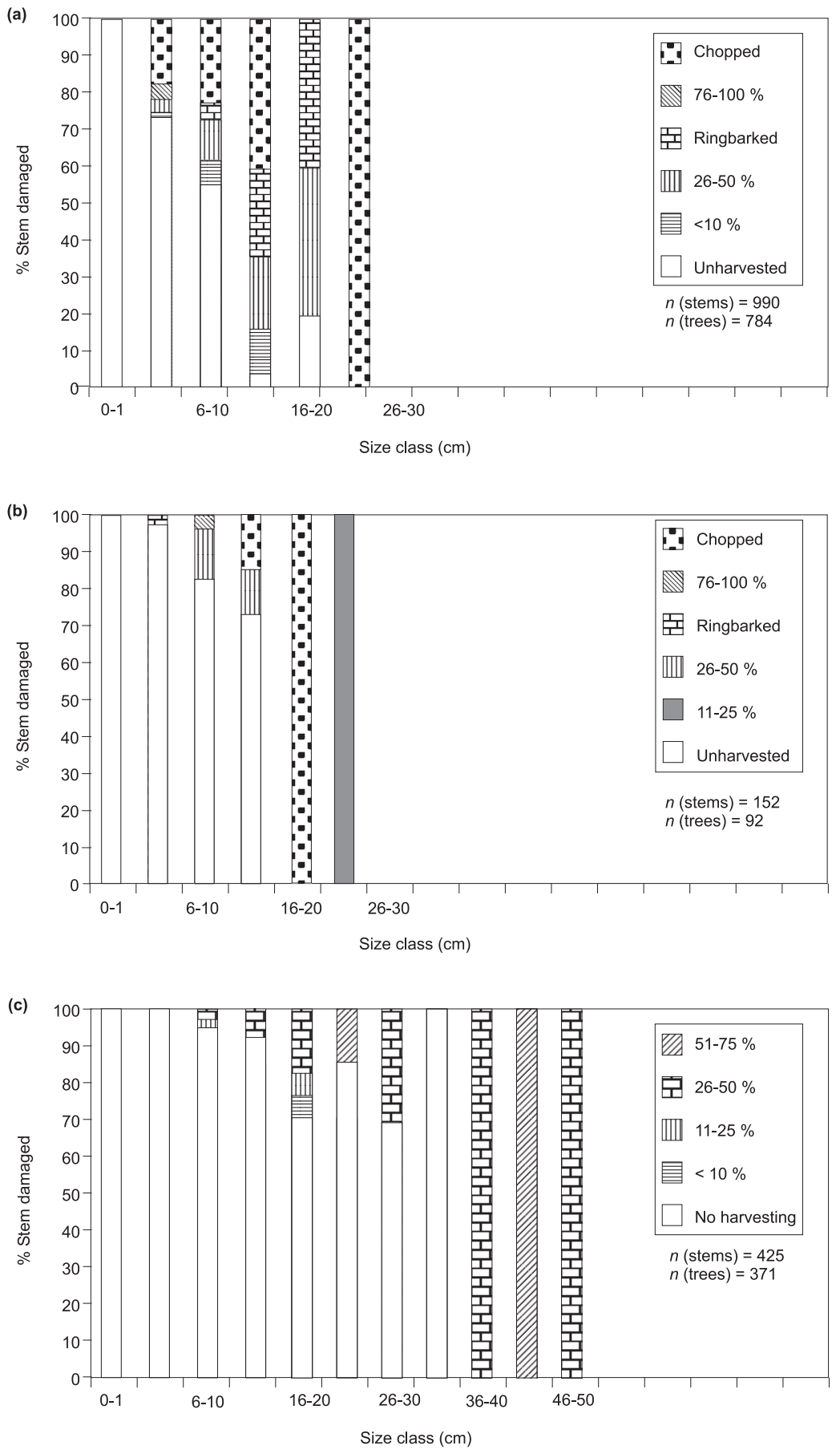

Fig. 4(a-c). Degree of stem damage to harvested Catha edulis through harvesting of bark below $2 \mathrm{~m}$ on the stem, and chopping of stems in populations situated (a) adjacent to a village near Barberton; (b) approximately $3 \mathrm{~km}$ from the village; (c) on a forestry plantation near Barberton. 
Table 2

Extent of harvesting of Catha edulis and Rapanea melanophloeos populations (Mean $\pm S E$ ) and condition of the harvested stems.

(Range in brackets under the mean) (\# statistical analysis not performed as $n=0$ in one or more cells)

\begin{tabular}{|c|c|c|c|c|c|c|c|}
\hline & \multicolumn{3}{|c|}{ C. edulis } & \multicolumn{3}{|c|}{ R. melanophloeos } \\
\hline & & Harvested & Unharvested & $p$ & Harvested & Unharvested & $p$ \\
\hline \multicolumn{2}{|l|}{$\begin{array}{l}\text { Proportion of stems of } \\
\text { harvestable size (\%) }\end{array}$} & $\begin{array}{l}38 \pm 12 \\
(9-71) \\
\end{array}$ & $\begin{array}{l}54 \pm 20 \\
(34-73) \\
\end{array}$ & $p<0.01$ & $\begin{array}{c}19.2 \pm 3.8 \\
(7-31)\end{array}$ & $\begin{array}{c}59.0 \pm 21.0 \\
(28-80)\end{array}$ & $p<0.01$ \\
\hline \multirow[t]{3}{*}{$\begin{array}{l}\text { Proportion of stems } \\
\text { harvested }\end{array}$} & -trunk & $\begin{array}{l}35.6 \pm 13.9 \\
(7-76)\end{array}$ & $\begin{array}{c}0.03 \pm 0.02 \\
(0-0.05)\end{array}$ & \# & $\begin{array}{c}26.8 \pm 8.5 \\
(9-57)\end{array}$ & $\begin{array}{l}1.0 \pm 1.0 \\
(0-2.0)\end{array}$ & \# \\
\hline & -roots & $\begin{array}{c}14.0 \pm 7.8 \\
(0-42)\end{array}$ & 0 & \# & 0 & 0 & \# \\
\hline & $\begin{array}{l}\text {-trunk \& } \\
\text { roots }\end{array}$ & $\begin{array}{l}7.6 \pm 4.4 \\
(2-24)\end{array}$ & 0 & $\#$ & 0 & 0 & $\#$ \\
\hline \multirow[t]{3}{*}{$\begin{array}{l}\text { Condition of } \\
\text { harvested trees }\end{array}$} & -dead & $\begin{array}{c}4.8 \pm 3.0 \\
(2-17)\end{array}$ & 0 & \# & $\begin{array}{c}8.6 \pm 5.4 \\
(4-29)\end{array}$ & 0 & \\
\hline & -stressed & $\begin{array}{c}1.2 \pm 1.1 \\
(0-9)\end{array}$ & 0 & \# & $\begin{array}{c}0.6 \pm 0.6 \\
(0-3)\end{array}$ & 0 & \\
\hline & -alive & $\begin{array}{l}96.5 \pm 3.2 \\
(74-100)\end{array}$ & 100 & $\#$ & $\begin{array}{c}90.4 \pm 55.1 \\
(71-100)\end{array}$ & 100 & \\
\hline
\end{tabular}

There was a significantly higher proportion of individuals in size class $0-1 \mathrm{~cm}$ in the harvested compared with the unharvested ones (48 \% and $18 \%$, respectively). In the harvested populations, $13 \%$ and $3 \%$ of the population had survived to size classes 6-10 cm and 11-15 cm, respectively. In the unharvested $R$. melanophloeos, $19 \%$ of the population had survived to size class 6-10 cm and $11 \%$ to $11-15 \mathrm{~cm}$.

Quotients were relatively stable in both the harvested and unharvested $C$. edulis populations (Fig. 2b), although they were more variable in the latter. Both populations, but particularly the harvested, showed steeper distributions than would be expected from an exponentially declining distribution (Table 1 ). Neither the harvested nor the unharvested populations deviated substantially from a monotonic decline.

Quotients between numbers of trees in successive size classes showed more variation in the unharvested $R$. melanophloeos populations than in the harvested ones (Fig. 3b). Both harvested and unharvested populations had steeper size frequency distributions than would be expected from an exponentially declining distribution (Simpson's Index of Dominance $=0.67$ and 0.28 , respectively), particularly the former (Table 1). Neither population deviated substantially from a monotonic decline.

\section{Harvesting impact}

There was a highly significant difference in the proportion of stems of harvestable size between the harvested and unharvested $C$. edulis populations ( $38 \pm 12 \%$ and $54 \pm 20 \%$, respectively) $\left(\chi^{2}=175.9 ; d f=1 ; p<0.0001\right)$ (Table 2). No C. edulis had been harvested on the private farm near Hazyview, and less than $0.1 \%$ of the protected area populations had been utilised. The extent of utilisation of harvested C. edulis populations ranged from $7-76 \%$ of the harvestable stems (36 \pm $14 \%), 0-42 \%$ of the roots (14 $\pm 8 \%$ ) and $2-24 \%(8 \pm 4 \%)$ of roots and stems harvested on the same tree.

The degree of harvesting was high in the $C$. edulis populations adjacent to settlements and roadsides, although the harvesting patterns varied. The majority of larger stems had been intensively harvested ( $>26 \%$ of the 

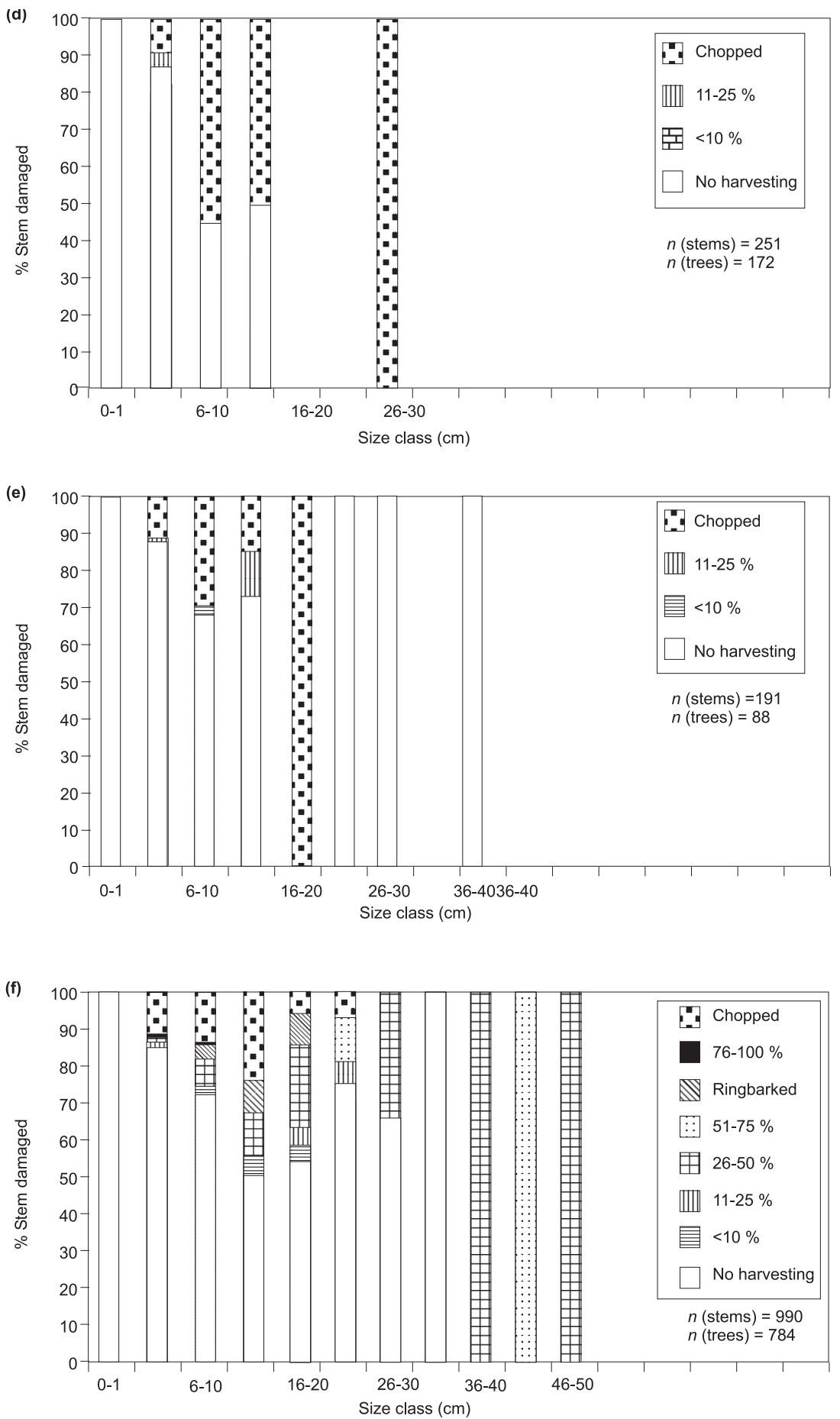

Fig. 4(d-f). Degree of stem damage to harvested Catha edulis through harvesting of bark below $2 \mathrm{~m}$ on the stem, and chopping of stems in populations situated (d) on communal land in Nsikazi; (e) on the roadside near Hazyview and (f) pooled populations. 
Table 3

Proportion of harvested and unharvested Catha edulis and Rapanea melanophloeos populations that were coppicing or single stemmed (\# statistical analysis not performed as $n=0$ in one or more cells)

\begin{tabular}{|c|c|c|c|c|c|}
\hline Species & Populations & Individuals & $\begin{array}{c}\% \\
\text { coppicing }\end{array}$ & $\begin{array}{l}\% \text { single } \\
\text { stemmed }\end{array}$ & $p$ \\
\hline \multirow[t]{6}{*}{ C. edulis } & \multirow[t]{2}{*}{ Total population } & Harvested & 45 & 55 & \multirow[t]{2}{*}{$p<0.01$} \\
\hline & & Unharvested & 86 & 14 & \\
\hline & \multirow[t]{2}{*}{ Harvested } & Harvested individuals & 56 & 44 & \multirow[t]{2}{*}{$p<0.05$} \\
\hline & & Unharvested individuals & 40 & 60 & \\
\hline & \multirow[t]{2}{*}{ Unharvested } & Harvested individuals & 100 & 0 & \multirow[t]{2}{*}{$\#$} \\
\hline & & Unharvested individuals & 85 & 15 & \\
\hline \multirow{6}{*}{ R. melanophloeos } & \multirow[t]{2}{*}{ Total population } & Harvested & 45 & 55 & \multirow[t]{2}{*}{$p<0.01$} \\
\hline & & Unharvested & 30 & 70 & \\
\hline & \multirow[t]{2}{*}{ Harvested } & Harvested individuals & 23 & 77 & \multirow[t]{2}{*}{$p<0.05$} \\
\hline & & Unharvested individuals & 48 & 52 & \\
\hline & \multirow[t]{2}{*}{ Unharvested } & Harvested individuals & 100 & 0 & \multirow[t]{2}{*}{ \# } \\
\hline & & Unharvested individuals & 31 & 69 & \\
\hline
\end{tabular}

stem below $2 \mathrm{~m}$ ) in the $C$. edulis populations growing adjacent to the village near Barberton, with extensive ringbarking taking place (Fig. 4a). Of the ringbarked individuals, $80 \%$ had died, and $10 \%$ showed signs of stress. Chopping had also occurred across all size classes. Both the degree and extent of harvesting was lower in the population situated approximately $3 \mathrm{~km}$ from the village, although the level of exploitation was high, with the majority of stems in the three largest size classes (basal diameters 15-25 cm) having been utilised. Limited ringbarking had occurred. Limited harvesting of bark had occurred in the population on communal lands and the roadside population near Hazyview. Here, the bulk of harvesting was for poles for building materials (Figs. 4d \& 4e).

In the most remote forestry population, $C$. edulis had only been harvested for medicinal materials (Fig. 4c). Only $15 \%$ of the harvestable trees had been utilised, the majority of which had occurred in the highest size classes (basal diameters 36-50 cm). Although the degree of harvesting in these size classes was high (26-75\%), no stems had been ringbarked.

Roots had been utilised at all the harvested sites, with the exception of the one situated approximately $3 \mathrm{~km}$ from a village in the Barberton area. The majority of individuals in the larger size classes had been harvested at intensities $>26 \%$ of their root circumference (Fig. 5). C. edulis roots had been harvested most extensively at the roadside site, with $42 \%$ of the population having been affected at degrees of $26-50 \%$ of their circumference (Fig. 5d). On the forestry site, roots of all the individuals in the largest size classes $(36-50 \mathrm{~cm})$ had been utilised (Fig. 5b). Stems and roots had also been harvested from the same trees, with the highest percentage occurring on the roadside site (24\%).

A significantly higher proportion of $R$. melanophloeos were of harvestable size in the unharvested populations, compared with those that had been harvested $\left(\chi^{2}=190.0\right.$; $d f=1 ; p<0.0001)(59 \pm 21 \% \& 19 \pm 4 \%$, respectively; Table 2 ). In the harvested populations, $27 \pm 9 \%$ of trees had been utilised. The degree and extent of harvesting was high in both the forestry populations near Barberton and the population on communal land near Hazyview. The majority of stems in the largest size classes (basal diameters $21-45 \mathrm{~cm}$ ) of the forestry populations had been utilised at levels $>10 \%$, with a considerable proportion having been harvested at 

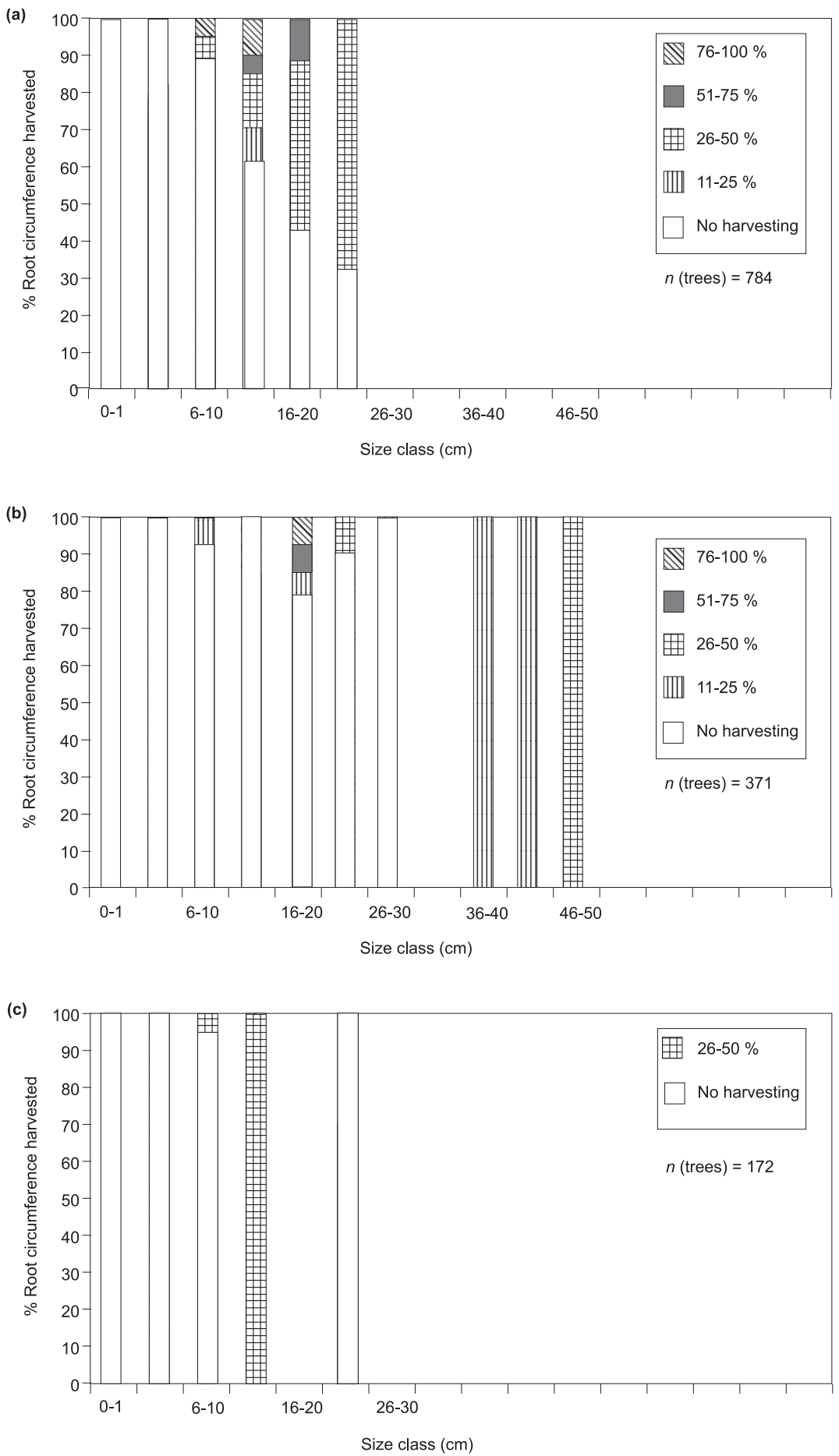

Fig. 5(a-c). The degree of root disturbance through harvesting of Catha edulis at sites (a) adjacent to a village and (b) in a forestry plantation near Barberton; (c) on communal land populations. 
between 51 and 75 \% (Figs. 6a \& 6b). Only one $R$. melanophloeos stem had been chopped in the forestry populations. Harvesting pressure in the population located close to communal lands was high from size class $11-15 \mathrm{~cm}$ and larger, with either chopping or ringbarking occurring in all these size classes. No harvesting had occurred in the population located close to Hazyview.

There was no significant difference between the proportions of dead, alive or stressed $C$. edulis in the harvested and unharvested populations. C. edulis appears resilient to harvesting, with the percentage survival of harvested trees ranging from $74-100 \%(97 \pm$ $3 \%$; Table 2). Only a few trees appeared stressed after harvesting $(1 \pm 1 \%)$ or had died $(5 \pm 3 \%)$. The majority of the stressed or dead individuals had been ringbarked. The percentage survival of harvested individuals ranged from $71-100 \%$ on the harvested sites
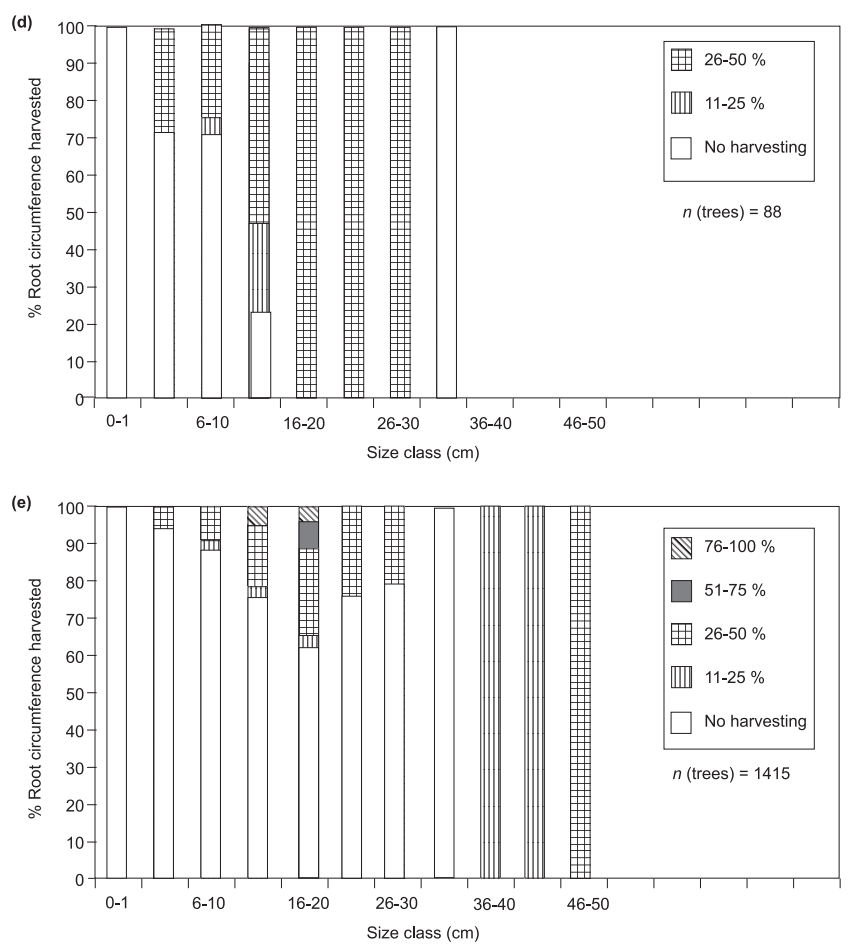

Fig. 5(d-e). The degree of root disturbance through harvesting of Catha edulis at sites (d) a roadside site near Hazyview, and (e) pooled populations.
(90 $\pm 55 \%$; Table 2). Between $4 \%$ and $29 \%$ of the harvested stems had died $(9 \pm$ 5), and $0.6 \pm 0.6 \%$ appeared stressed. All the $R$. melanophloeos on the unharvested sites appeared healthy.

\section{Coppicing}

The number of stems per tree in harvested C. edulis was significantly lower than in the unharvested ones $(1.4 \pm 0.03 \& 7.0 \pm 0.9$, respectively). There was also a highly significant difference in the proportions of multi-stemmed trees growing in harvested and unharvested populations. In the former populations, $45 \%$ of the $C$. edulis were coppicing, compared with $86 \%$ coppicing in the unharvested populations (Table 3).

Within the harvested populations, a significantly higher proportion of harvested individuals were coppicing (56\%), compared with the proportion of unharvested trees that were multi-stemmed $(40 \%)$. In the unharvested populations, all harvested individuals were coppicing $(n=4)$, as were $85 \%$ of the unharvested .

There was no significant difference between the numbers of stems per tree in harvested $R$. melanophloeos $(1.5 \pm 0.04$ stems) vs unharvested populations (1.6 \pm 0.1 stems) $\left(U_{862,227}\right.$ $=99$ 856; $p>0.05)$. There was, however, a highly significant difference between the proportions of trees coppicing in the harvested and unharvested populations $\left(\chi^{2}=10.9 ; d f=1 ; p\right.$ $<0.0001)$. In the latter, $30 \%$ of the trees were coppicing, while $45 \%$ of the harvested population were multi-stemmed (Table 3). Within the harvested populations, the proportion of utilised individuals that were coppicing was significantly lower than the proportion of 
unharvested individuals that were multistemmed ( $23 \%$ and $48 \%$, respectively) $\left(\chi^{2}\right.$ $=4.4 ; d f=1 ; p<0.05)$.

There was a relationship between the height of chopping of Catha edulis stems, and the number of stems per individual $\left(r^{2}=0.19\right.$; $p<0.05$ ) (Fig. 7), but no relationship between the basal diameter of a chopped stem and the number of coppices $\left(r^{2}=\right.$ 0.003; $p>0.05$ ). There were insufficient data to test this relationship with Rapanea melanophloeos stems, as only five stems had been chopped.

\section{Discussion}

Species respond to disturbance differently, depending on where they fit along the continuum between $K$ and $r$ strategists (Primack 1993; Shackleton et al. 1994). Significant decreases have been found in stem density, basal area, biomass, height, young plant density and species richness when certain woody species are subject to human disturbance (Rao et al. 1990; Shackleton et al. 1994; Clarke 1997). In others, pioneers for example, the opposite has been found (Rao et al. 1990; Shackleton et al. 1994). In this study, the densities of harvested populations were higher than for the unharvested, although not statistically significant for $R$. melanophloeos.

Fig. 6. Degree of stem damage to harvested Rapanea melanophloeos through harvesting of bark below $2 \mathrm{~m}$ on the stem, and chopping of stems in populations located on (a) and (b) a forestry plantation near Barberton and (c) near Nsikazi.
In both species, the densities of young plants were higher in the harvested populations compared with the unharvested. While the frequency of plants in size class 1 was high, numbers in subsequent size classes was limited in populations that had been extensively harvested. C. edulis has been observed in fruit at heights of 2-3m (pers. comm. G. Strydom, Mpumalanga Parks Board 2000). In the harvested populations $22 \%$ of the $C$. edulis were $>2 \mathrm{~m}$, compared with $36 \%$ in the unharvested populations. Within the heavily harvested population on the commu-
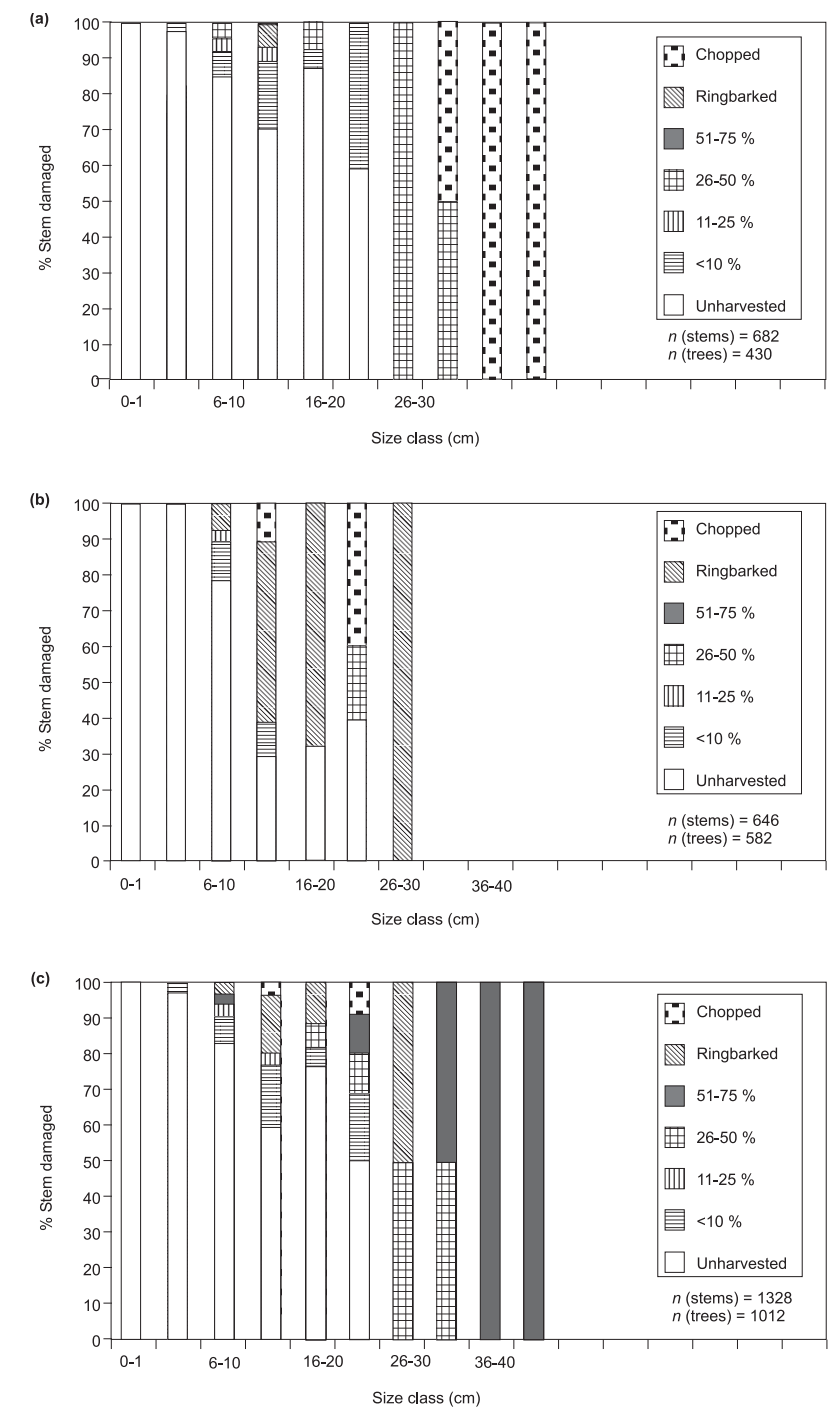


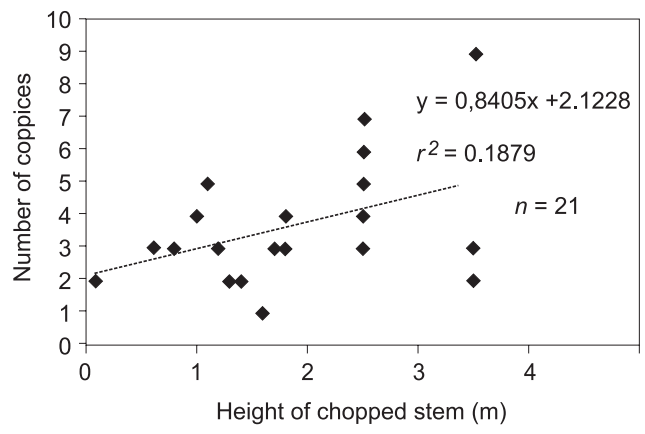

Fig. 7. Relationship between the height of chopping and the number of coppices for Catha edulis.

nal site near Hazyview, only $4 \%$ of individuals were taller than $2 \mathrm{~m}$. The approximate size at which $R$. melanophloeos produces seed is unknown, but was estimated to be between 4 and $6 \mathrm{~m}$, depending on growth form (pers. comm. G. Strydom, Mpumalanga Parks Board 2000; pers. comm. W. Froneman, Nelspruit Botanic Gardens 2000). In the harvested population, $12 \%$ were $>2 \mathrm{~m}$, while $24 \%$ of the unharvested population were $>2 \mathrm{~m}$. Only $3 \%$ of the harvested and $13 \%$ of the unharvested $R$. melanophloeos were $>4$ metres.

Basal diameters and heights were significantly lower in the harvested populations than in the unharvested, with high levels of chopping in certain $C$. edulis populations. Growth may also have been inhibited through physiological stress resulting from harvesting (Hall \& Bawa 1993). A decrease in mature trees diminishes the sexual reproductive potential of a population through a lowering of seed production which, if unchecked, could lead to a total loss of sexual reproduction in a population, although $C$. edulis and $R$. melanophloeos are able to regenerate successfully vegetatively (Van Wyk 1988). The communal and roadside $C$. edulis populations also had a reduced number of size classes, which also may lower the probability of long-term persistence in a population if harvesting pressure is maintained (Harper 1977).
As often occurs in woody populations where wide climatic fluctuations, fire, herbivory and harvesting pressures are experienced (Walker et al. 1986), both the harvested and unharvested $R$. melanophloeos populations appeared unstable. The $C$. edulis population were relatively more stable. The size frequency distributions of all the populations were steeper than would be expected from an exponentially declining population ( $\mathrm{C}$ values $>0.1$ ). The $C$ values of harvested populations were higher than those of the unharvested, showing steeper size frequency distributions in the former through selective harvesting of trees in higher size classes. The harvested $R$. melanophloeos and unharvested $C$. edulis populations showed the highest levels of monotonic decline $(p=2)$, while the size classes of the harvested $C$. edulis and unharvested $R$. melanophloeos populations were more discontinuous ( $p=4$ and 6 , respectively), the former due in part to the extensive chopping of poles on the communal and roadside sites.

Many savanna species have adapted to herbivory and regular dry season fires by coppicing from surviving rootstocks, often resulting in multi-stemmed trees (Bond \& Van Wilgen 1996; Luoga et al. 2004). A significantly higher proportion of harvested $C$. edulis individuals were coppicing within the harvested populations, compared with the unharvested trees in the same populations. The high level of coppicing in the unharvested $C$. edulis populations can be attributed to other forms of disturbance. The $C$. edulis population at one site in Songimvelo Game Reserve was growing along a stream that was subject to periodic flooding. At the other site, $12 \%$ of the population showed signs of having been burnt. None of the harvested $C$. edulis sites showed additional signs of disturbance, apart from the sites adjacent to the rural villages. Although only $1 \%$ of these stems had been burnt, this area is subject to regular burning by residents to improve the quality of grazing for livestock.

Similarly, the higher proportion of unharvested $R$. melanophloeos stems that were coppicing in the harvested populations is 
probably due to fire. The forestry plantation sites are currently burned every two years, but were burnt annually until recently. The commercially harvested population growing close to communal lands was relatively protected from fire, with only $0.6 \%$ of the $R$. melanophloeos individuals showing signs of having been burnt. The unharvested population was also protected from fire, as it grows in a sheltered position beneath a granite outcrop; $80 \%$ of the $R$. melanophloeos in this population were single stemmed.

While all the populations assessed, apart from the $C$. edulis growing on the roadside and the communal area, appear to be withstanding current levels of harvesting, they may become vulnerable if utilisation increases, which is possible as harvesters from KwaZulu-Natal attempt to locate new harvesting areas to replace those where populations have become locally extinct (Williams et al. 2000). Higher levels of bark removal are also likely to decrease the plants' ability to withstand regular fires. Fire also suppresses the growth of young plants and saplings in particulatr. The combined effects of harvesting and fire diminishes the regeneration capacity of both species.

In India and Tanzania, for example, different harvesting patterns were discernible in plant populations subject to different land management regimes, with distinct gradients in harvesting intensity corresponding to the accessibility of populations to human settlements (Chandrashekara \& Sankar 1998; Luoga et al. 2000, 2004). The extent and degree of harvesting in C. edulis populations near settlements and along the roadside was high. The C. edulis population growing adjacent to the village near Barberton had been more intensively utilised than the one located approximately $3 \mathrm{~km}$ from the village, with both roots and bark being harvested. Adjacent to the village, stems had been chopped in $23 \%$ of the population across all size classes, while in the population further from the village, only $3 \%$ of the stems had been chopped. No harvesting for roots had occurred in the latter. The extent and degree of harvesting in the population located with- in the forestry plantation approximately $15 \mathrm{~km}$ from the nearest human settlement was substantially lower and no poles had been extracted. The largest $C$. edulis individuals assessed during this study were growing on the forestry site, and there were greater proportions of individuals in the larger size classes. Limited harvesting of bark had occurred in the C. edulis populations growing in the communal areas and on the roadside near Hazyview, although extensive harvesting for roots had occurred, particularly on the latter site. Poles had been extensively chopped in both populations.

It is unlikely that the $R$. melanophloeos populations growing on the forestry plantations were being harvested for commercial purposes at the time of the study. Although 26-75\% of the bark had been removed below $2 \mathrm{~m}$ from the stems in the largest size classes, these comprised a relatively small proportion of the population and the overall extent of harvesting was relatively low. Few stems had been chopped or ringbarked. The population near communal lands was being harvested by vendors for bark to trade on local markets. It is more likely that the chopped stems were being utilised for building materials than for medicinal purposes, though, as $R$. melanophloeos bark was still within easy reach of the harvesters. In KwaZulu-Natal, species such as Ocotea bullata are chopped to enable harvesters to access bark in the higher reaches of the tree, once the lower bark has been harvested.

In an Eastern Cape study, all the trees ringbarked some time prior to the assessment had died-including $R$. melanophloeos (La Cock \& Briers 1992). The proportion of trees surviving ringbarking in this study was also low, with only $20 \%$ of the ringbarked $C$. edulis surviving. In a concurrent study, $27 \%$ of the assessed Warburgia salutaris had survived ringbarking; the remainder had either died or showed signs of stress (Botha et al. 2004b).

Apart from the ringbarked trees, the percentage survival of harvested $C$. edulis and $R$. melanophloeos plants was high, including 
individuals of the former species that had been harvested for both roots and bark. Species with good coppicing ability have been shown to be less vulnerable to anthropogenic disturbances than those with poor coppicing ability. Both $C$. edulis and $R$. melanophloeos exhibited high levels of coppicing after both natural (fire) and anthropogenic disturbance. This corresponds to results obtained for $C$. edulis in a previous survey conducted at Songimvelo (Mbewe et al. 1997). In a study on the impact of harvesting on woody species (including Dalbergia melanoxylon, Spirostachys africana, Acacia ataxacantha and Combretum imberbe) in Limpopo, all the recently harvested trees had survived and over $70 \%$ of the harvested stems of each species were coppicing (Clarke 1997). In another study investigating the impact of chopping on savanna trees in the same area, all the chopped stumps had coppiced (Shackleton 2000). In this study, 86 $\%$ of the chopped C. edulis stems had coppiced. Only five $R$. melanophloeos stems had been chopped, four of which were coppicing.

The basal diameter of the stem and the height at which a stem was chopped may affect the coppicing success of certain species. With an increase in harvesting height, there was a decrease in the number of shoots produced by C. imberbe, A. ataxacantha and, to a lesser degree, D. melanoxylon in the central Lowveld (Clarke 1997). In addition, the higher the harvesting height the longer the shoot length, possibly due to livestock grazing the shoots of the shorter tree stumps (Clarke 1997). The opposite occurred with $C$. edulis in this study; there was an increase in the number of stems with an increase in harvesting height (Botha 2001). This corresponds to other observations that coppicing vigour decreases when trees are cut low down (Wild \& Mutebi 1996; Shackleton 2000; Luoga et al. 2004). There was no relationship between harvesting height and the heights of coppices in either $C$. edulis or $W$. salutaris populations, or the basal diameter and number of coppices in either species (Botha 2001).
This study has highlighted the different harvesting patterns on $C$. edulis and $R$. melanophloeos under different management regimes. In both species, basal diameters, heights, and the number of size classes in the harvested populations were lower than in unharvested. Densities of harvested populations were higher in both species, including densities of young plants, but the frequency of individuals in higher size classes was lower. The populations of both species being harvested for medicinal products appeared to be withstanding the current levels of harvesting, but the population structure of $C$. edulis populations being harvested for poles on the roadside and near human settlements had been substantially altered. The $C$. edulis and R. melanophloeos populations situated within forestry plantations appeared the most vigorous. Despite the resilience of the two species to harvesting for medicinal products, loss of habitat or changes in land use pose a threat to a number of the assessed populations. For example, the $R$. melanophloeos population growing near the communal lands was located on a remnant patch of indigenous vegetation, surrounded by plantations. The C. edulis population growing on communal land in Nsikazi was located between two homesteads; it is quite possible that this land could be allocated for settlement or agriculture in the future. On the banana farm near Hazyview, a similar site to the remnant patch of open woodland on which the $C$. edulis was growing was cleared for cultivation two years prior to the survey. Although the farmer was conservation conscious (he had granted traditional healers and other local user groups harvesting access approximately one year prior to the bush clearing), the land may be converted if economic conditions dictate.

\section{Acknowledgements}

This study was funded by The Green Trust. The Kruger National Park and University of the Witwatersrand are thanked for logistical support. The following people are thanked for their assistance with field surveys: Mr Dup Du Plessis, Mr Elijah Lekhulene, Ms Josephina Hloliwe Silinda, Mr Phillip Pap- 
pin, Mr Ernst Schmidt, Mr King Khoza, Mr Andries Mathonsi and Sipho.

\section{References}

Bond, W.J. \& B. VAN Wilgen. 1996. Fires and plants. Cambridge: Cambridge University Press.

Bотна, J. 1998. Developing an understanding of problems being experienced by traditional healers living on the western border of the Kruger National Park: foundations for an integrated conservation and development programme. Development Southern Africa 15: 621-634.

BотнA, J. 2001. Perceptions of species availability and values of medicinal plants traded in areas adjacent to the Kruger National Park. M.Sc thesis, University of the Witwatersrand, Johannesburg.

Botha, J., E.T.F. WitKowski \& C.M. SHACKLETON. 2001. An inventory of the medicinal plants traded on the western boundary of the Kruger National Park, South Africa. Koedoe 44(2): 7-46.

Botha, J., E.T.F. WITKOWSKI \& C.M. SHACKLETON. 2004a. Market profiles and trade in medicinal plants in the Lowveld, South Africa. Environmental Conservation 31: 38-46.

BotHA, J., E.T.F. WitKoWSKi \& C.M. SHACKLETON. 2004b. The impact of commercial harvesting on Warburgia salutaris ('pepper-bark tree') in Mpumalanga, South Africa. Biodiversity \& Conservation 13: 1675-1698.

BOTHA, J., E.T.F. WITKOWSKI \& C.M. SHACKLETON \& D.H.K. FAIRBANKS (in press). Socio-economic differentiation in the trade of wildlife species for traditional medicines in the Lowveld, South Africa: implications for resource management. The International Journal of Sustainable Development and World Ecology.

BraedT, O. \& W. STANDA-Gunda. 2000. Woodcraft markets in Zimbabwe. International Tree Crops Journal 10: 367-384.

Cawe, S.G. \& M. NtLoKo. 1997. Distribution, uses and exploitation patterns of Flagellearia guinensis Schumach. with particular reference to Port St. Johns, South Africa. South African Journal of Botany 63: 233-238.

ChANDRASHEKARA, U.M. \& SANKAR, S. 1998. Ecology and management of sacred groves in Kerala, India. Foresty Ecology and Management 112: 165-177.

Clarke, A.B. 1997. Sustainability of harvesting seven favoured plant species used in the indigenous wood carving industry in the Bushbuckridge district of the Northern Province Lowveld. Honours dissertation, University of the Witwatersrand, Johannesburg.
CROoK, C. \& R.A. Clapp. 1998. Is market-orientated forest conservation a contradiction in terms? Environmental Conservation. 25: 131-145.

Cunningham, A.B. 1992. Imithi isiZulu: the traditional medicine trade in Natal/KwaZulu. M. Soc Sci. dissertation, University of Natal, Pietermaritzburg.

Godoy, R.A. \& K.S. BAwA. 1993. The economic value and sustainable harvest of plants and animals from the tropical forest: assumptions, hypotheses and methods. Economic Botany 47: 215-219.

GRIME, J.P. 1979. Plant strategies and vegetation processes. Chichester: Wiley.

Hall, P. \& Bawa, K. 1993. Methods to assess the impact of extraction of non timber forest products on plant populations. Economic Botany 47: 234-247.

HARPER, J.L. 1977. Population biology of plants. San Diego: Academic Press.

Hilton-TAYloR, C. 1996. Red data list of southern African plants. Strelitizia 4: 1-117.

HOFFMAN, M.T. 1997. Human impacts on vegetation. Pp 507-534. In: CoWling, R.M., RichardSON, D.M. \& Pierce, S.M. (eds.). Vegetation of southern Africa. Cambridge: Cambridge University Press.

Konstant, T.L., S. Sullivan \& A.B.Cunningham. 1995. The effects of utilization by people and livestock on Hyphaene petersiana (Arecaceae) basketry resources in the palm savanna of northcentral Namibia. Economic Botany 49: 345-356.

LA CoCK, G.D. \& J.H. BRIERs. 1992. Bark collecting at Tootabie Nature Reserve, Eastern Cape, South Africa. South African Journal of Botany 58: 505-509.

Lambin, E.F., B.L. Turner, H.J. Geist, S.B. AgBoLA, A. Angelsen, J.W. Bruce, O.T. CoOmes, R. Dirzo, G. Fischer, C. Folke, P.S. GeORge, K. Homewood, J. Imbernon, R. LeEMANS, X. LI, E.F. Moran, M. MorTIMORE, P.S. RAMAKRISHNAN, J.F. RichaRdS, H. SKÅNES, W. STEFFEN, G.D. Stone, U. Svedin, T.A. VeldKamp, C. Vogel \& J. XI. 2001. The causes of land-use and land-cover change: moving beyond the myths. Global Environmental Change 11: 261-269.

Letsela, T., E.T.F. WitKowsKi \& K. BALKWILl. 2003. Plant resources used for subsistence in Tsehlanyane and Bokong in Lesotho. Economic Botany 57: 619-639.

Low A.B. \& A.G. RebeLo. 1996. Vegetation of South Africa, Lesotho and Swaziland. Pretoria: Department of Environment Affairs and Tourism.

LuOGA E.J., E.T.F. WiTKOWSKI \& K. BALKWILL. 2000. Economics of charcoal production in miombo woodlands of Eastern Tanzania: some hidden costs associated with commercialisation of the resources. Ecological Economics 35: 243-257. 
LUOGA E.J., E.T.F. WITKOWSKI \& K. BALKWILl. 2002. Harvested and standing wood stocks in protected and communal miombo woodlands of eastern Tanzania. Forest Ecology and Management 164: 15-30.

LUOGA E.J., E.T.F. WITKOWSKI \& K. BALKWILL. 2004. Regeneration by coppicing (resprouting) of miombo (African savanna) trees in relation to land use. Forest Ecology and Management 189: 23-35.

MANDER, M. 1997. Medicinal plant marketing in Bushbuckridge and Mpumalanga: a market survey and recommended strategies for sustaining the supply of plants in the region. Nelspruit: Darudec/Department of Water Affairs and Forestry.

MANDER, M. 1998. Marketing of indigenous medicinal plants in South Africa. A case study in Kwazulu-Natal. Rome: Food and Agricultural Organisation of the United Nations (FAO).

MARSHALL, N.T. 1998. Searching for a cure: conservation of medicinal wildlife resources in East and southern Africa. Cambridge: Traffic International.

Mbewe, M.N., J.A. Cooke \& B.R. Page. 1997. Plant resource availability, utilisation and management in and around Songimvelo Game Reserve, South Africa. Internal report. Centre of Indigenous Plant Use Research, Dept of Biology, University of Natal, Durban.

MeYer, H.A. 1952. Structure, growth and grain in balanced uneven-aged forests. South African Journal of Forestry 50: 85-92.

Pielou, E.C. 1977. Mathematical Ecology. New York, NY: Wiley.

PRIMACK, R.B. 1993. Essentials of conservation biology. Massachusetts: Sinauer.

RaO, P., S.K. Barik, H.N. Pandey \& R.S. TRIPATHI. 1990. Community composition and tree population structure in a sub-tropical broad-leaved forest along a disturbance gradient. Vegetatio 88: 151-162.

ShaCKLETON, C.M. 1993. Demography and dynamics of the dominant woody species in a communal and protected area of the eastern Transvaal Lowveld. South African Journal of Botany 59: 569-574.

SHACKLETON, C.M. 2000. Stump size and the number of coppice shoots for selected savanna tree species. South African Journal of Botany 66: 124-127.

Shackleton, C.M., N.J. GrifFin, D.I. BanKs, J.M. MAVRANDONIS \& S.E. SHACKLETON. 1994. Com- munity structure and species composition along a disturbance gradient in a communally managed South African savanna. Vegetatio 115: 157-167.

Shackleton, C.M. \& S.E. Shackleton. 2000. Direct use values of savanna resource harvested from communal savannas in the Bushbuckridge Lowveld, South Africa. Journal of Tropical Forest Products 6: 21-40.

Shackleton, S.E., C.M. Shackleton, T.R. NetSHILUVH, B.S. GEACH, A. BALLANCE \& D.H.K. FAIRBANKS. 2002. Use patterns and value of savanna resources from three rural villages in South Africa. Economic Botany 56: 130-146.

VAN WYK, B., B. VAN OUdTSHOORN \& N. GeRICKe. 1997. Medicinal plants of South Africa. Pretoria: Briza.

VAN WYK, P. 1988. Field guide to the trees of the Kruger National Park. Cape Town: Struik.

Walker, B.H., L. Stone, L. Henderson \& M. VERNEDE. 1986. Size structure analysis of the dominant trees in a South African savanna. South African Journal of Botany 52: 397-402.

Wiegand, K., D. Ward, H.H. ThulKe \& F. Jeltsch. 2000. From snapshot information to long-term population dynamics of Acacias by a simulation model. Plant Ecology 150: 97-114.

Wild, R.G. \& J. MuteBI, J. 1996. Conservation through community use of plant resources. Establishing collaborative management at Bwindi Impenetrable and Mgahinga Gorilla National Parks, Uganda. France: United Nations Educational, Scientific and Cultural Organisation.

Williams, V.L., K. BALKWILl \& E.T.F. WitKOWSKI. 2000. Unravelling the commercial market for medicinal plants and plant parts on the Witwatersrand. Economic Botany 54: 310-327.

WiLliams, V.L., K. BALKWILL \& E.T.F. WiTKOWSKI. 2001. Checklist of plants used in the Muthi trade on the Witwatersrand, South Africa. Bothalia 31: 71-98.

Wilson, B.G. \& E.T.F. WitKowsKi. 2003. Seed banks, bark thickness, and changes in age and size structure (1978-1999) of the African savanna tree, Burkea africana. Plant Ecology 167: 151-162.

WitKowski E.T.F., B.B. LAMONT \& F.J. OBbens. 1994. Commercial picking of Banksia hookeriana in the wild reduces subsequent shoot, flower and seed production. Journal of Applied Ecology 31: 508-520. 